\title{
Innovation on International Business Talent Training Model: A Case Study of Innovation Classes from GDUFS
}

\author{
Xuyang LIU, Wenzhong ZHU * \\ School of English for International Business, Guangdong University of Foreign Studies, Guangzhou 510420, \\ China
}

\begin{abstract}
This research intends to make a case analysis of innovation of international business talent training of the higher education in China by taking the three types of innovation classes of Guangdong University of Foreign Studies (GDUFS) as an example, which mainly analyzes specific steps of how to train the undergraduate from the perspectives of innovation of admission, innovation of curriculum design, innovation of teaching resource allocation and innovation of teaching method, etc. It finds that the innovation classes have conducted successful innovations in student admission, curriculum design, etc., but there are areas of improvement.
\end{abstract}

KEYWORD: Talent training; International business talent; Innovation class; GDUFS; Case analysis

\section{INTRODUCTION}

With the blossom of Chinese economy, more suitable international business talents who can perform well in the international business are in great need. Although China's pool of university graduates is enormous, graduates who process the necessary skills to perform in the international business activities are few. New research from the McKinsey Global Institute (MGI) suggests that fewer than 10 percent of Chinese job candidates, on average, would be suitable for working in a foreign company, and the fast-growing domestic economy absorbs most of those who could. China is now confronted with great shortage of international business talent, and the reform and innovation of Chinese higher education is extremely urgent.

As the reform experimental area of international business talent training mode of the ministry of education and the internationalized talents cultivation base, GDUFS is putting great efforts on the innovative training of international business talents with both professional business knowledge and good English proficiency in order to better satisfy the ever-growing needs of Chinese economy. The setting up of innovation classes is a good example to illustrate the innovative training of international business talent of GDUFS.

This paper will make a case analysis of the practice of the innovative model in international talents training in China by taking innovation classes of GDUFS as an example, which are International
Business Innovation class, International Trade and Economics Innovation class, and International Accounting Innovation class. This paper analyzes the specific approach on how the international business talent training mode is carried out from several aspects of the selection of the students, the curriculum design and the teaching method, etc. It intends to bring some implications for facing the trend of innovation of other Chinese universities having similar degree programmes.

\section{LITERATURE REVIEW}

\subsection{Researches on theories of innovation}

The definition of innovation is the use of the existing knowledge and material to make improvement or create new things in a specific environment which can get a benefit. The concept of innovation was first put forward by the Austrian American economists J.A. Schumpeter in his work Instability of Capitalism in 1928. Later, P.F Drucker (1985) points out that innovation is not confined to technology and innovative activity is to endow new power to resources to create wealth. With the broadening of the research scope, it began to cover some specific area such as education, health care, social welfare, etc. Many scholars started to further expand the concept of innovation. In 1992, OECD adopted a more broad concept of innovation and expand the concept to all kinds of field including education. 


\subsection{Researches on higher education innovation}

In China, the study on innovation of higher education was few before the 1990s. While with the process of opening and reform being accelerated, innovation of higher education began to be taken seriously. Qiu(1999) argues that the inheritance education should be converted into innovative education and that the essence of innovation on talent training mode is to solve the problem of the structure of the courses to form a new course system among which the content innovation is the key and difficult points. Li (2003) pointed out that the modernization of higher education is the ultimate goal of higher education and the innovation of higher education is the effective way to realize the modernization of higher education. Similarly, Xu (2010) mentioned that the training of the innovative talents who can perform well in the international market is a most important task currently. Zhou (2013) argues the great significance of the reform and internalization of higher education for the realization of the function of cultural innovation keeping balance between Chinese native culture and international culture.

\subsection{Research on international business talent training innovation}

The existing researches are mainly about the innovation of international talent training with few research concerning the innovation of international business talent training. Zhao (2010) makes a study on the innovative international talent training model of universities of electronic information, and argues that the universities should update the education conception to broaden the vision on innovative international talent training and focus on the training of practical capability.

$\mathrm{Pu}$ and $\mathrm{Zou}$ (2013) argue that foreign teaching should contain more international elements, which means to set up international courses using the textbooks of original version to let the students know the world advanced culture thoroughly as well as add more traditional Chinese cultures to cultivate students' intercultural communication capability.

Due to the shortage of research in the innovation of international business talent training, it is necessary to explore in this field to make some contributions based on the following analysis framework for the present research (See Figure 1):

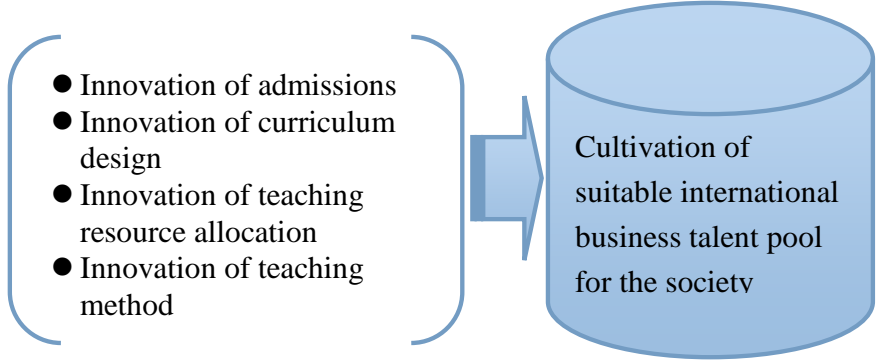

Figure 1 Analysis framework for the present research

\section{A CASE STUDY OF INNOVATION CLASSES FROM GDUFS}

\subsection{General introduction of the three innovation classes in GDUFS}

The International Business Innovation Class follows the training mode of "international business plus business English". The graduates can be awarded the international business professional qualification certificate registered in the ministry of education and a second major (business English major) diploma issued by GDUFS if qualified. Meanwhile, qualified graduates will be conferred two degrees ---bachelor's degree of management and bachelor's degree of art, otherwise, only one degree will be awarded if the graduates failed to meet the evaluation standard.

The International Trade and Economics Innovation Class follows the training mode of "international trade and economics major plus English major". Similarly, the qualified graduates will be conferred the international trade and economics professional qualification certificate registered in the ministry of education and a second major (English major) diploma issued by GDUFS if qualified. The students will be managed by both the School of English Language and Culture and School of International Trade and Economics. For the first two semesters, the students will be in the charge of the School of English Language and Culture so as to make a solid language foundation while School of International Trade and Economics will finish the training task for the last six semesters including the uncompleted English major curriculum.

The International Accounting Innovation Class has the cooperation with the Association of Chartered Certified Accounts. The undergraduates are supposed to register for the ACCA examination. The graduates will be awarded by the bachelor's degree in management if qualified. Meanwhile, the training focuses on the students' practical education in order to improve the students' competence of starting business and job hunting. Many teaching and internship bases are built outside the campus through cooperation with some famous enterprises by cooperating with some famous enterprises such as the Ernst \&Young, Price Waterhouse Coopers, PWC, Lixin Accounting firm, Pearl River Shipping company (HK), Kingdee International Software to strengthen the graduates competitiveness of job hunting.

\subsection{Innovation of admissions}

The students in innovation classes are strictly selected from the freshmen by a series of test including interviews and written examination, which is actually a second round of selection from the top 
students enrolled. International Business Innovation Class and International Trade and Economics Innovation Class give an interview to examine the comprehensive quality of the candidates. Then based on the each candidate's performance, candidates who are thrice of the admitted students will have the chance to take the written examination for English and Mathematics. The professional courses are all taught in English or in bilingual language. The professional textbooks are original English versions of economics, management and law.

For the International Business Innovation Class, all freshmen have the qualification to participate in the selection. In terms of the International Trade and Economics Innovative Classes and International Accounting Innovation Classes (ACCA), they recruit students from the non-language major freshmen. Each candidate can apply only one innovation class.

\subsection{Innovation of curriculum design}

The curriculum of the International Business Innovation Class is taking reference from top universities worldwide. Professional business courses from international prestigious universities such as Harvard University, Lancaster University, Queensland University are brought in to build up the international classes, but there are also some distinctive differences between them (See Table 1).

Table 1. Comparison of Core Curriculum of International Business Innovation Class and Traditional International Business Class

\begin{tabular}{|c|c|}
\hline $\begin{array}{l}\text { International Business } \\
\text { Innovation Class }\end{array}$ & $\begin{array}{l}\text { Traditional International } \\
\text { Business Class }\end{array}$ \\
\hline $\begin{array}{l}\text { - Advanced business English } \\
\text { Writing } \\
\text { - Practice of International } \\
\text { Trade Affairs } \\
\text {-E-commerce management } \\
\text { and practice } \\
\text {-International Business } \\
\text { Etiquette } \\
\text {-Enterprise research report/ } \\
\text { Business Case analysis } \\
\text {-Scientific research method } \\
\text {-Intellectual property law } \\
\text {-International Finance } \\
\text {-Enterprise Resource Planning } \\
\text {-Probability theory/Calculus }\end{array}$ & $\begin{array}{l}\text {-Business English Writing } \\
\text {-Higher Mathematics } \\
\text {-Principles of Management } \\
\text {-Principles of Accounting } \\
\text {-Principles of Marketing } \\
\text { - International Commercial } \\
\text { Law } \\
\text {-Intermediate Financial } \\
\text { Accounting } \\
\text {-Human Resource } \\
\text { Management } \\
\text {-Operation Management } \\
\text {-Consumer Behavior } \\
\text {-Strategic Management } \\
\text {-Electronic Commerce } \\
\text { Management }\end{array}$ \\
\hline
\end{tabular}

Based on the existing courses of International Business major, the innovation class has added some new courses, for instance, the Enterprise Research Report/ Business Case analysis, E-commerce management and practice, Advanced Business English Writing and so forth. Meanwhile, courses about the international laws and standards and etiquette are designed to the students in the curriculum, for example, International Trade Law, Intellectual Property Law, and International Business Etiquette. Moreover, more courses about mathematics are set up to the students to cultivate the preciseness and logicality and lay solid foundation for their future study on finance and accounting and so forth. Also courses like Scientific Research Method aims to cultivate the independent learning and research-oriented ability.

\subsection{Innovation of teaching resource allocation}

The objective of International Business Innovation Class is to cultivate international business talents who are proficient in professional knowledge of economics, management and law as well as in English skills. From this aspect, the superior teaching resources from related schools of the whole university are integrated and organized to teach the innovation class. The innovation classes are built by a strong teaching faculty consisting of professors, star teachers and promising young teachers who take the teaching task of about 50\% to ensure the teaching quality. Moreover, high-level teachers overseas are invited to give lectures to the innovation classes during the vacation of universities, especially from U.K. and U.S.

In order to give more customized guidance to different students, the innovation class complements the tutorial system to personalize every student's learning plan. The tutor will make personalized learning plans based on the university's general training objectives, the talent training objective of the innovation class and students' personal intention to give guidance to the students from the admission to the graduation of the university.

\subsection{Innovation of teaching method}

An internationalized teaching method is adopted by the innovation classes. Following the international top universities' advanced education concept and method, the innovation classes aim to build up firstrate teaching modes and give students customized guidance to promote an enlightenment-oriented, research-oriented, and exploration-oriented interactive learning mode. Meanwhile, the evaluation system has also been innovated by augmenting the proportion of the peacetime study assessment. Both independent learning and researchoriented learning are brought into the course evaluation system to ensure the quality of these innovation classes' teaching and learning practices.

In addition, the training of English skills and cross-cultural communication competence is greatly valued in the teaching of innovation classes. First, the teaching hour in the classroom has been adjusted from 18 weeks to 16 weeks, while the additional 2 weeks is designed to have the practical teaching and 
innovation education activity. Second, the innovation class has formed an open united cultivation mode with MNCs and other famous enterprises. Internship bases are built through the cooperation with international famous enterprises such as PWC, DTT, KPMG, EY, HSBC, Bank of China, Southern China Airline, Huawei, and so forth. Third, the innovation class has built a Mobile Classroom by cooperation with famous enterprise to let the students communicate with entrepreneurs face to face and get close to the operation and management of the enterprise. Students are required to participate at least 8 Mobile Classroom teaching tasks during 4 years' study. Fourth, more than 20 entrepreneurs and top managers are invited to be the second tutor and give lectures to the students to get the knowledge of the current business environment.

In this way, the students could experience how to apply the management conception into the real practice and also provide some strategies for the development of the enterprise based on the what they have learned in the class.

\section{CONCLUSION AND IMPLICATION}

The paper finds that the innovation classes in GDUFS have conducted innovations in the following aspects at the same time of pursuing the core feature of education internationalization: for example, innovatively select the most excellent students from the whole university to study in the innovation class to ensure the students' quality; innovatively design the curriculum to let the students learn comprehensive knowledge of both business professions and English and International business standards and etiquette; innovate the teaching resource allocation and implement the tutorial system to provide customized guidance to each student; implement the international teaching method to value more on the peacetime study assessment and training of practical and applicable ability. By this approach the students could both master professional business knowledge and good English proficiency with a global vision.

This case analysis brings the following implications to the Chinese universities for facing the trending of reform and innovation: first, the institutes of higher education should update the education concept and keep up with the development of social need; second, the teaching resources including teaching staff and teaching materials should be integrated to teach the students more efficiently and effectively; third, the training focus should shift to the training of practical ability and independent-learning ability and so forth. It is advisable to train students through the cooperation with enterprises to train their ability to apply knowledge into practical use.

\section{ACKNOWLEDGMENTS}

This paper is sponsored by the A-level Undergraduate Teaching Research Project of Guangdong University of Foreign Studies No.Guangwai [2013]83 and the Provincial Academic Degree and Postgraduate Teaching Reform Project No. Yuegaojiaohan [2012]123.

\section{REFERENCES}

[1] J.A. Schumpeter. (1928). The Instability of Capitalism. The Economic Journal.

[2] Li Qingzhang. (2003). The Innovation and Modernization of Higher Education. Heilongjiang Research on Higher Education. No.114. 1-3

[3] Peter F. Drucker. (1985). The Discipline of Innovation. Harvard Business Review.

[4] Pu Yu, Zou Dan. (2013). New Development of International of Higher Educatiton and Their Implication on Foreign Language Education. Foreign Language Learning Theory and Practice. No.2. 66-71

[5] Qiu Kunrong. (1999). Innovative Education and Higher Education Innovation. Journal of Nanjing University of Posts and Telecommunications (Social Science) Vol.1 No. 3 1-4

[6] Xu Qing. (2010). A Study on Training Model of Innovative Talent in the perspective of Internationalization of Higher Education. Continuing Education Research. Vol.9 57-58

[7] Zhang Wei. (2003). The Management and Paradigm of Higher Education Innovation: Integration Innovation. China Soft Science. 1-7

[8] Zhao Bo, Zhang Zhihua. (2010). A Study on Innovative International Talent Training: take universities of electronic information as an example. Heilongjiang Research on Higher Education, 138-140.

[9] Zhou Dengchao. (2013). Cultural Innovation: Localization and Internationalization of China's Higher Education. International Conference on Education, Management and Social Science (ICEMSS). 1-4

[10] http://www.mckinsey.com/insights/china/addressing_china s_looming_talent_shortage 